\title{
Digestive enzyme activities in different size groups and segments of the digestive tract in labeo rohita (day, I878)
}

\begin{abstract}
Variations in the activities of some digestive enzymes were studied in the different size groups of Indian major carp, Labeo rohita. Regional distribution of digestive enzymes was also investigated from four intestinal segments of adult fish. The activities of amylase, trypsin, total protease and chymotrypsin increased along with increase in length and weight of the fish, having its highest value in the size group with $35.44 \pm 3.2 \mathrm{~cm}$ and $549.67 \pm 117.0$ g compared to smaller and bigger fish. Hepatosomatic index and digestive somatic index declined with increase in fish size. Relative gut length showed an increasing trend up to size group with $26.22 \pm 2.7 \mathrm{~cm}$ and $227.3 \pm 44.5 \mathrm{~g}$ and thereafter stabilised. Activity of amylase was the highest (at both $\mathrm{pH} 4.5$ and 7) in proximal intestine as compared to other segments. Cellulase activity was the highest in distal intestine and absent in hepatopancreas. The proximal intestine exhibited the highest activity for all the proteases, followed by anterior bulb and the rest of the segments; hepatopancreas recorded the least proteases activity.
\end{abstract}

Volume 4 Issue 5 - 2016

\author{
Umalatha, Sridhar N, Kushwaha JP, \\ Gangadhar B \\ Regional Research Center, ICAR-Central Institute of Freshwater \\ Aquaculture (CIFA), India
}

Correspondence: Gangadhar Barlaya, ICAR-Central Institute of Freshwater Aquaculture, Regional Research Centre, Hesaraghatta Lake P.O., Bangalore, India, Email gbarlaya@yahoo.co.in

Received: October 28, 2016 | Published: November 29, 2016

\section{Introduction}

In culture operations, the efficiency of a feed in promoting maximum growth in animal depends not only on its nutritive profile, but also on the animal's inherent ability to consume, digest, absorb and metabolize the nutrients from the feed. Nutrient utilization in aquatic animals depends on the activity of their digestive enzymes. ${ }^{1,2}$ Digestive processes in fish are less known than in animals, though the data obtained in fish so far show that the digestive enzymes studied are qualitatively similar to those observed in other invertebrates. It is known that age and/or stage of development significantly influences the digestive enzyme activity in different fish species, ${ }^{3,4}$ which can be used as a basis to develop feed formulation suitable for different sizes of fishes, so that optimal nutritional values and cost-effectiveness can be obtained. Further, the ability of fish to utilize ingested nutrients depends on the presence of appropriate enzymes in appropriate locations in the wall and along the lumen of the intestinal tract. Generally, distribution and intensity of intestinal enzyme activity along the gut varies with feeding habits and intestinal morphology. ${ }^{5-7}$

Labeo rohita(rohu) is the most preferred species for polyculture among the Indian major carps. Though digestive enzyme activity has been estimated in the gastrointestinal tract of Indian major carps, ${ }^{8-12}$ there is no literature on their activities in different size groups and segments of the digestive tract. Rohu shows a clear dietary preference to certain plant and animal protein diets. The physiology of digestion in this species seems to be more complicated and needs a detailed study. In the present study, we have determined and correlated the activities of amylase and proteases (trypsin, chymotrypsin and total proteases) in the digestive tract of L. rohita of different size groups with biometric parameters. Further, we have also determined the activity of digestive enzymes in different segments of the digestive tract.

\section{Materials and methods}

Fifty healthy rohu fish of different size were taken from one of the stock ponds of our research centre. They were divided into five groups based on length. Their weights in relation to length were recorded. The average length and weight recorded in various size groups were $7.04 \pm 2.18 \mathrm{~cm}$ and $4.81 \pm 1.66 \mathrm{~g}$ for Group $1,12.49 \pm 2.1 \mathrm{~cm}$ and $25.02 \pm 6.2 \mathrm{~g}$ for Group 2, $26.22 \pm 2.7 \mathrm{~cm}$ and $227.3 \pm 44.5 \mathrm{~g}$ for Group 3, $35.44 \pm 3.2 \mathrm{~cm}$ and $549.67 \pm 117.0 \mathrm{~g}$ for Group 4 and 45.22 $\pm 2.9 \mathrm{~cm}$ and $1132 \pm 245.9 \mathrm{~g}$ for Group 5. The length and weight of the intestine (IN) and weight of hepatopancreas (HP) were recorded. The tissues were then homogenized in ice cooled condition with distilled water $(4 \mathrm{ml} / \mathrm{g})$ and centrifuged at $16,000 \mathrm{rpm}$ for $20 \mathrm{~min}$ at $4{ }^{\circ} \mathrm{C}$.

The biometric parameters like relative length of the gut (RLG), hepatosomatic index (HSI) and digestive somatic index (DSI) were calculated using the following formulae.

$$
\begin{gathered}
\text { Hepatosomatic index }=\frac{\text { Hepatopancreas weight }(\mathrm{g})}{\text { Body weight }(\mathrm{g})} \times 100 \\
\text { Digestive somatic index }=\frac{\text { Intestine weight }(\mathrm{g})}{\text { Body weight }(\mathrm{g})} \times 100 \\
\text { Relative length of the gut }=\frac{\text { Length of the Intestine }(\mathrm{cm})}{\text { Total length of fish }(\mathrm{cm})}
\end{gathered}
$$

\section{Screening for digestive enzymes in the different segments of intestine}

For segment study, nine specimens of $L$. rohita (average length and weight $16.31 \pm 3.28 \mathrm{~cm} ; 48.11 \pm 37.85 \mathrm{~g}$ ) were obtained from the stock ponds of our research centre. The digestive tract and hepatopancreas of the specimens were dissected under ice cooled conditions. The intestine was divided into 4 parts, viz., first $10 \mathrm{~cm}$ (anterior bulb), the remaining portion into three equal parts (proximal, middle, posterior). The tissues were homogenized individually with distilled water $(4$ $\mathrm{ml} / \mathrm{g} ; 15 \mathrm{~g}$ tissue in $60 \mathrm{ml}$ ) and centrifuged at $16,000 \mathrm{rpm}$ for 20 min at $4{ }^{\circ} \mathrm{C}$. The supernatants (crude enzyme extract) were frozen and stored at $-20{ }^{\circ} \mathrm{C}$ in $20 \mathrm{ml}$ aliquots for use in further studies. Total soluble protein of the homogenate was measured using Folin-phenol reagent. ${ }^{13}$ 
Total proteolytic activity was determined by the casein digestion method of Kunitz. ${ }^{14}$ The assay mixture contained $0.1 \mathrm{ml}$ crude enzyme extract plus $2.0 \mathrm{ml}$ of casein buffer substrate and was incubated at $28{ }^{\circ} \mathrm{C}$ for $15 \mathrm{~min}$. The resulting tyrosine was determined using tyrosine as the standard. Trypsin activity was assayed using $\mathrm{N}$-abenzoyl DL-arginine p-nitro anilide hydrochloride (BAPNA) as the substrate in Tris - $\mathrm{HCl}(0.04 \mathrm{M}, \mathrm{pH}$ 8.2) buffer containing $0.02 \mathrm{M}$ $\mathrm{CaCl} 2$. The reaction mixture consisted of $2.9 \mathrm{ml}$ of substrate buffer solution and $0.1 \mathrm{ml}$ of crude enzyme extract incubated at $25{ }^{\circ} \mathrm{C}$ for $10 \mathrm{~min}$. Chymotrypsin activity was assayed against $1 \mathrm{mMN}-$ Benzoyl L-tyrosine p-nitro anilide (BTNA) in $30 \mathrm{ml}(95 \%)$ ethanol in $50 \mathrm{ml}$ distilled water. The reaction was carried out by the addition of 1.5 $\mathrm{ml}$ of substrate to a mixture containing $1.4 \mathrm{ml}$ Tris - $\mathrm{HCl}$ buffer $(0.1$ $\mathrm{M} \mathrm{pH} 7.8$ ) containing $0.1 \mathrm{M} \mathrm{CaCl}_{2}$ and $0.1 \mathrm{ml}$ crude enzyme extract. The activities of trypsin and chymotrypsin were calculated from the increase in absorbance at $410 \mathrm{~nm}$ for $10 \mathrm{~min}$ at $25^{\circ} \mathrm{C}$ using p-nitro aniline as the standard. ${ }^{15}$ Amylase activity was estimated by using $1 \%$ starch solution in Tris- $\mathrm{HCl}$ buffer $(0.1 \mathrm{M}, \mathrm{pH} 7.0)$ as the substrate. The assay mixture contained $0.05 \mathrm{ml}$ crude enzyme extract and 1.0 $\mathrm{ml}$ of substrate. Incubation was carried out at $25^{\circ} \mathrm{C}$ for $60 \mathrm{~min}$. The resulting reducing sugars were determined using glucose as the standard. ${ }^{16}$ Cellulase activity was estimated by using $0.5 \%$ carboxy methyl cellulose in Tris- $\mathrm{HCl}$ buffer $(0.1 \mathrm{M}, \mathrm{pH} 7.0)$ as substrate. The assay mixture contained $0.05 \mathrm{ml}$ of crude enzyme extract and $1.0 \mathrm{ml}$ of substrate. Incubation was carried out at $25{ }^{\circ} \mathrm{C}$ for $60 \mathrm{~min}$.
The resulting reducing sugars were determined using glucose as the standard. ${ }^{16}$

\section{Screening for carbohydrases in the intestine}

The crude enzyme extract of digestive enzymes extracted from the intestine of adult rohu (weight $450 \mathrm{~g}$ and length $35.6 \mathrm{~cm}$ ) was screened for carbohydrase activity using different substrates namely starch, amylose, carboxy methyl cellulose, cellobiose, maltose, lactose, sucrose. The reducing sugars liberated were estimated. ${ }^{16}$ The activity obtained using starch as the substrate is reconciled as $100 \%$ and compared with other substrates to obtain the percent utilization.

\section{Results}

Weight and length of intestine and weight of hepatopancreas, relative gut length exhibited significant $(\mathrm{P}<0.01)$ positive correlation with total length and total weight of fish (Table 1). In contrast, HSI and DSI exhibited significant $(\mathrm{P}<0.01)$ negative correlation. Relative length of the gut exhibited an increasing trend up to Group 4 and then stabilised. The condition factor ranged from 1.22 (Group 5) to 1.37 (Group 1). Activities of digestive enzymes in different size groups of rohu are given in Figure1. The activity of amylase and total protease exhibited an increasing trend with size up to Group 3, decreasing thereafter. Trypsin and chymotrypsin activities also exhibited a similar trend with the highest activity in the size Group 2.

Table I Relationship between biometric parameters and size groups of $L$. rohita $($ Mean $\pm S D ; n=9)$

\begin{tabular}{|c|c|c|c|c|c|}
\hline Parameter & Group I & Group 2 & Group 3 & Group 4 & Group 5 \\
\hline Weight of HP (g) & $0.09 \pm 0.02^{\mathrm{a}}$ & $0.398 \pm 0.09^{a}$ & $2.32 \pm 0.40^{b}$ & $5.69 \pm 0.7^{c}$ & $8.53 \pm 1.10^{d}$ \\
\hline $\mathrm{HSI}$ & $2.08 \pm 0.14^{c}$ & $1.79 \pm 0.20^{c}$ & $\mathrm{I} .07 \pm 0.08^{\mathrm{ab}}$ & $1.22 \pm 0.10^{\mathrm{b}}$ & $0.75 \pm 0.07^{a}$ \\
\hline Length of IN (cm) & $29.2 \pm 3.49^{a}$ & $82.5 \pm 7.76^{b}$ & $232 \pm 4.63^{c}$ & $335 \pm 3.64^{d}$ & $431.4 \pm 6.2^{\mathrm{e}}$ \\
\hline Weight of IN (g) & $0.18 \pm 0.03^{a}$ & $1.24 \pm 0.17^{\mathrm{a}}$ & $9.02 \pm 0.98^{b}$ & $14.03 \pm 0.89^{c}$ & $14.75 \pm 2.32^{c}$ \\
\hline DSI & $5.70 \pm 0.69^{\mathrm{cd}}$ & $5.94 \pm 0.43^{d}$ & $4.50 \pm 0.3 I^{b c}$ & $3.31 \pm 0.52^{b}$ & $1.25 \pm 0.09^{a}$ \\
\hline RLG & $4.13 \pm 0.19^{a}$ & $6.50 \pm 0.27^{b}$ & $9.01 \pm 0.35^{c}$ & $9.53 \pm 0.46^{c}$ & $9.52 \pm 0.23^{c}$ \\
\hline Condition factor & 1.37 & 1.28 & 1.26 & 1.23 & 1.22 \\
\hline
\end{tabular}

Mean values in the same column with different superscripts are significantly different $(P<0.05)$.

HP- Hepatopancreas; HSI- Hepatosomatic index; IN- Intestine; DSI- Digestive somatic index; RGL-Relative gut length.

Table 2 Distribution of digestive enzymes in the hepatopancreas and intestinal segments

\begin{tabular}{|c|c|c|c|c|c|c|}
\hline Segments & Amylase (pH 4.5) & Amylase (pH 7.0) & Cellulase & Total protease & Trypsin & Chymotrypsin \\
\hline $\mathrm{AB}$ & $29.1 \pm 3.7^{b}$ & $17.8 \pm 3.4^{b}$ & $6.5 \pm 0.6^{\mathrm{b}}$ & $16.6 \pm 3.8^{b}$ & $1.7 \pm 0.1^{\mathrm{b}}$ & $1.0 \pm 0.2^{\mathrm{ab}}$ \\
\hline $\mathrm{PI}$ & $51.7 \pm 2.1^{d}$ & $39.0 \pm 3.4^{c}$ & $6.6 \pm 0.5^{b}$ & $48.6 \pm 5.6^{c}$ & $2.8 \pm 0.3^{c}$ & $2.2 \pm 0.3^{b}$ \\
\hline MI & $39.3 \pm 5.3^{\mathrm{bc}}$ & $32.6 \pm 5.1^{b c}$ & $8.1 \pm 0.5^{b}$ & $6.0 \pm 2 . I^{a}$ & $1.0 \pm 0.4^{\mathrm{ab}}$ & $1.2 \pm 0.3^{\mathrm{ab}}$ \\
\hline DI & $47.3 \pm 2.8^{\mathrm{cd}}$ & $39.0 \pm 2.8^{c}$ & $14.9 \pm 1.5^{c}$ & $0.3 \pm 0.02^{\mathrm{a}}$ & $0.2 \pm 0.0 \mathrm{I}^{\mathrm{a}}$ & $1.6 \pm .02^{\mathrm{b}}$ \\
\hline $\mathrm{HP}$ & $16.0 \pm I . I^{a}$ & $9.4 \pm 1.0^{\mathrm{a}}$ & $0 \pm 0^{\mathrm{a}}$ & $0.1 \pm 0.02^{\mathrm{a}}$ & $0.02 \pm 0.00^{\mathrm{a}}$ & $0.1 \pm 0.1^{\mathrm{a}}$ \\
\hline
\end{tabular}

Activity (Mean $\pm \mathrm{SD} ; \mathrm{n}=9$ ) expressed in $\mu$ moles $\mathrm{hr}-\mathrm{I} \mathrm{mg}$ protein-I

Mean values bearing different superscripts in a column differ significantly $(P<0.05)$.

AB-Anterior bulb; PI-Proximal intestine; MI-Middle intestine; DI-Distal intestine; HP-Hepatopancreas.

Activities of the digestive enzymes were observed in all the four segments of intestine (Table 2). A marked difference was recorded in the regional distribution and localisation along the intestine as well as hepatopancreas. Isozymes of amylases with two $\mathrm{pH}$ optima were recorded. Maximum amylase activity of both $\mathrm{pH}$ optima 7.0 and 4.5 was detected in proximal intestine (PI) and distal intestine (DI). The activity of both the amylases was significantly $(\mathrm{P}<0.05)$ lower in HP as compared to segments of intestine. Cellulases were recorded along the intestine and maximum concentration was in the distal intestine (DI). No activity of cellulase was noticed in the HP. The proximal intestine $(\mathrm{PI})$ exhibited highest $(\mathrm{P}<0.05)$ activity of all the proteases, followed by anterior bulb $(\mathrm{AB})$ in comparison with the rest of the segments; HP recorded the least protease activity.

\section{Screening for carbohydrases in the intestine}

When the different substrates were hydrolysed, it was observed that the hydrolysis of amylose was high, followed by maltose and cellobiose, when compared with $100 \%$ hydrolysis of starch. Sucrase activity and $\beta$ - galactosidase activity were found to be absent in this fish (Figure 2).

\section{Discussion}

From the results, it was noted that the relative length of gut (RLG) of the rohu ranged between $4 \mathrm{~cm}$ to $9.5 \mathrm{~cm}$. Al- Hussaini ${ }^{17}$ pointed out that the relative length of the gut was clearly connected with the feeding habits of fishes, particularly related to the quantity of indigestible 
material ingested. According to them, the longest intestine is present in microphagous and some herbivorous fishes and the shortest one in carnivorous species while the varied intestinal length in omnivorous fishes is linked to the proportion of the indigestible to digestible materials in the diet. The present observation is in conformity with the earlier investigation on food and feeding habits of rohu by virtue of RLG, indicating microphagousor detritus feeding. ${ }^{18}$ Matthes ${ }^{19}$ observed a higher RLG of 15.5 in rohu. Hsu and $\mathrm{Wu}^{20}$ observed a RLG of 5.15, 5.28 for microphagous Carassius auratus \& Hypophthalmichthys molitrix respectively. Day et al. ${ }^{2}$ demonstrated a significant decrease in gut length relative to body size. In the present study, however, RGL exhibited positive correlation with total length and total weight of fish till the size Group 4. Thus, L. rohita by virtue of possessing an elongated intestine has more area, for absorption, resulting in complete and efficient digestion and assimilation of ingested diet. Condition factor is an indicator of general fish health conditions and the values obtained in the present study of greater than one showed the well-being of fishes selected for the study. ${ }^{2}$
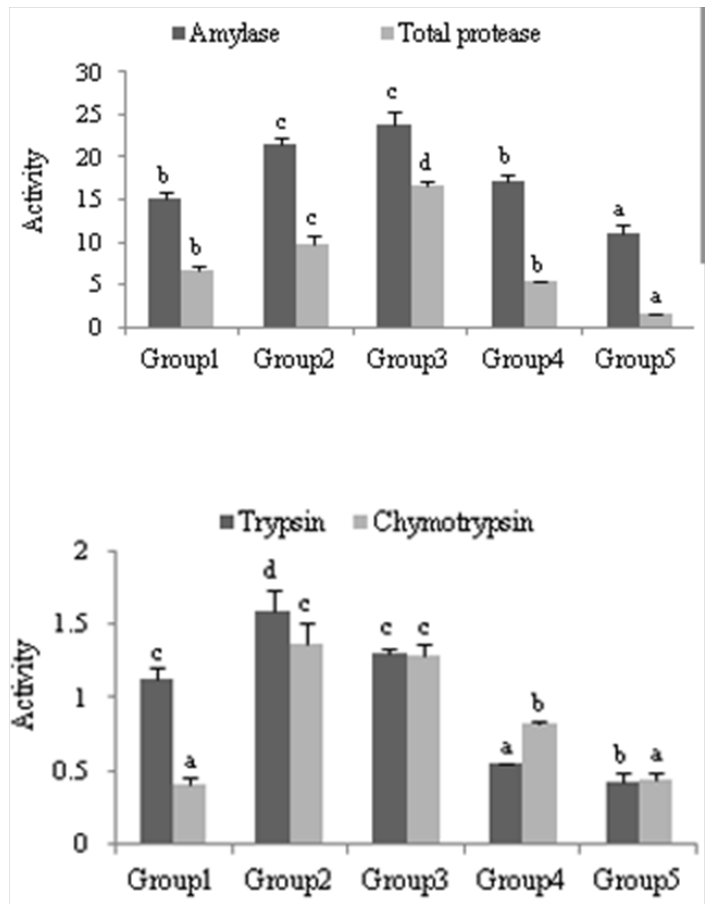

Figure I Digestive enzymes activities ( $\mu$ moles $/ \mathrm{hr} / \mathrm{mg}$ protein) in various size groups (mean \pm S.E) $(n=9)$.

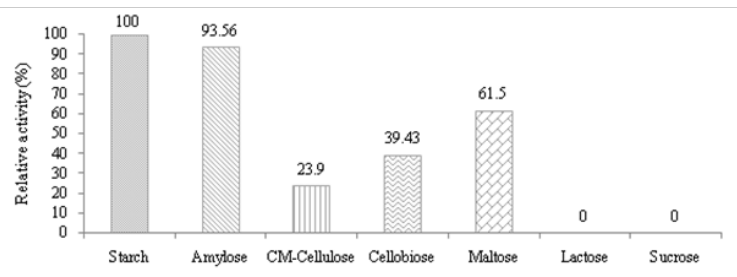

Figure 2 Relative activity (\%) of carbohydrases in the intestine of $L$. rohita compared to starch (100\%).

Determination of digestive enzyme activities in various size groups of fish will be useful in selecting the suitable low-cost feed stuffs with maximum digestibility. Total intestinal enzyme activity, as a rule, increases with fish age due to the increase in intestinal size. ${ }^{22}$ The best digestive capacity of the fish occurres during the early stages of their development. ${ }^{23,24}$ The highest level of enzyme activity was observed in larger fry of both bream (Abramis brama) and roach (Rutilus rutilus) in comparison with that observed in smaller fry of each species. However, no variation in intestinal proteolytic activity in the larger and smaller perch fry ${ }^{25}$ was observed. Chakrabarti et al. ${ }^{26}$ detected an exponential increase in activity of trypsin and chymotrypsin in L. rohita during ontogenesis. In Nile tilapia, activity of protease in the smaller fish (5.7 and $35.8 \mathrm{~g}$ ) was higher than that in the large fish $(92.1 \mathrm{~g}) .^{3}$ In the present study, in contrast, the activity of all enzymes showed a hyperbolic relationship with increase in length and weight of the fish, having its highest value in the middle sized groups, compared to smaller and bigger fish. Amylase and total protease showed highest activity in Group 3 $(20-30 \mathrm{~cm})$, while trypsin and chymotrypsin activity showed highest activity in group 2 (10-20 $\mathrm{cm})$. Akintunde. ${ }^{27}$ also observed similar trend in amylase activity, with fingerlings recording higher activity than fry and adult Sarotherodon galileau. Kitamikado \& Tachino. ${ }^{28}$ reported reduction in amylase activity with age in rainbow trout. Contrary to this, increase in amylase activity with the development and growth was observed in Ctenopharyngodon idella, Cyprinus and carpio. ${ }^{29,30}$ Limia vittate. ${ }^{4}$ while no variation with respect to growth was observed in the activity of amylase in Gambusia punctate. ${ }^{4}$

Several authors have reported digestive enzyme activity in fish and its distribution pattern in different segments of alimentary canal. ${ }^{31,7,32}$ Different sections of the gut do not necessarily possess the same capacity for the digestion and absorption of a given nutrient. Though many digestive enzymes are restricted to specific sections of digestive tract in contrast with other higher vertebrates.$^{33}$ amylase in fish is reported to be localised throughout the gastrointestinal tract.$^{34,35}$ Amylase is secreted more in the hepatopancreas than in the intestine of carps.$^{36}$ In the present study, activity of amylase was highest (at both $\mathrm{pH} 4.5$ and 7) in proximal intestine as compared to other segments. This finding is in accordance with the observation made by Parra et al. ${ }^{37}$ who found higher level of $\alpha$-amylase in proximal intestine compared to middle and distal intestine in Pacific blue fin tuna (Thunnus orientalis). This may be because starch digestion and glucose absorption occurs mainly in the anterior part of the intestine ${ }^{38}$ Highest amylase activity was detected in the lower part of the intestine in Channa striata, middle intestine in Notopterus notopterus and Puntius japonicus, oesophagusin O. niloticus, upper intestine in H.molitrix and C. carpio.$^{33}$ Similarly, Papoutsoglou \& Lyndon. ${ }^{39}$ reported higher amylase activity in the posterior intestine, followed by anterior intestine in parrot fish (Sparisomo cretense L).

Pancreatic secretions viz. trypsin and chymotrypsin play a key role in the digestive physiology of carps as they are devoid of the stomach. In the present study, total protease and trypsin activity were the highest $(\mathrm{P}<0.005)$ in the proximal intestine, followed by anterior bulb, as compared to the rest of the segments. Higher trypsin activity in the upper part of the intestine has been reported in C. isheriensis. ${ }^{40}$ gilthead sea bream. ${ }^{41}$ and grass carp. ${ }^{42}$ On the other hand, Uys \& Hecht. ${ }^{43}$ found higher activity of trypsin in the more posterior parts of the intestine of African catfish Clarias gariepinus (Burchell). In our study, no significant variation of chymotrypsin activity was found between different sections of the intestine, which tallies with the findings of Degura et al. ${ }^{41}$

Cellulase is mainly produced by fungi, bacteria and other cellulolytic organisms and catalyses the degradation of cellulose by hydrolysis. Cellulase activity in rohu is partially contributed by microbes and also by endogenous secretion. ${ }^{9}$ In the present study, cellulase activity was maximum in the distal intestine and absent in hepatopancreas. Saha \& Ray. ${ }^{44}$ also detected cellulase activity in 
the intestine but not in the HP of rohu fed with leaf meal based and synthetic cellulose. Das \& Tripati. ${ }^{45}$ on the contrary, reported cellulase activity in both hepatopancreas and intestine of grass carp (C. idella). Cellulase was also found in the anterior portion of the digestive tract of the carp by Shcherbina \& Kazlaskene. ${ }^{46}$

In L. rohita, amylose was hydrolysed to the maximum, followed by maltose and cellobiose, when compared with hydrolysis of starch. This shows that amylase is the main digestive enzyme in rohu. Clark et al. ${ }^{47}$ demonstrated substantial activity of maltase in the whole gut extracts of Dover sole, Solea solea. Kawai and Ikeda. ${ }^{48}$ and Sethuramalingam \& Haniffa. ${ }^{9}$ reported maltase activity in the mid gut of common carp and rohu, respectively. Since starch is the main storage product of plants, and maltose being the breakdown product of starch by the action of amylase, the presence of maltase in substantial amounts would ensure complete utilisation of starch in rohu which is a microphagous detritus eating herbivore. ${ }^{49}$ Sucrase activity and $\beta$ galactosidase activity were absent in rohu. However, in contrast to our result, Kawai and Ikeda. ${ }^{48}$ recorded sucrase activity in C. carpio.

\section{Conclusion}

The activities of amylase and proteases increased along with increase in length and weight of the fish, with highest value in the group $35.44 \pm 3.2 \mathrm{~cm}$ and $549.67 \pm 117.0 \mathrm{~g}$ compared to smaller and bigger fish; their activities were the highest in the proximal intestine compared to other parts. Highest cellulase activity was observed in distalintestine, whereas no cellulase activity was detected in hepatopancreas. The proximal intestine exhibited the highest activity for all the proteases, followed by anterior bulb and the rest of the segments; hepatopancreas recorded the least protease activity.

\section{Acknowledgments}

None.

\section{Conflicts of interest}

None.

\section{References}

1. Areekijseree M, Engkagul A, Kovitvadhi U, et al. Temperature and $\mathrm{pH}$ characteristics of amylase and proteinase of adult freshwater pearl mussel, Hyriopsis (Hyriopsis) bialatus, Simpson 1900. Aquaculture. 2004;234(1-4):575-587.

2. Day RD, German DP, Tibbetts IR. Why can't young fish eat plants? Neither digestive enzymes nor gut development preclude herbivory in the young of a stomach less marine herbivorous fish. Comp Biochem Physiol. 2011;158(1):23-29.

3. Klahan R, Areechon N, Yoonpundh R, et al. Characterization and activity of digestive enzymes in different sizes of Nile Tilapia (Oreochromis niloticusL.). Kasetsart J (Nat Sci). 2009;43:143-153.

4. Hidalgo FB, Barrios AF, Farnés OC, et al. Digestive enzymes of two freshwater fishes (Limia vittata and Gambusia punctata) with different dietary preferences at three developmental stages. Comp Biochem Physiol B Biochem Mol Biol. 2011;158(2):136-141.

5. Cockson A, Bourne D. Enzymes in the digestive tract of two species of euryhaline in fish. Comp Biochem Physiol A Comp Physiol. 1972;41(4):715-718.

6. Sabapathy U, Teo LH. A quantitative study of some digestive enzymes in the rabbitfish, Siganus canaliculatus and the sea bass (Lates calcarifer). J Fish Biol. 1993;42(4):595-602.
7. Tengjaroenkul B, Smith BJ, Caceci T, et al. Distribution of intestinal enzyme activities along the intestinal tract of cultured Nile tilapia, Oreochromis niloticus L. Aquaculture. 2000;182(3-4):317-327.

8. Gangadhara B, Nandeesha MC, Varghese TJ, et al. Effect of varying protein and lipid levels on the growth of rohu, Labeo rohita. Asian Fish Sci. 1997;10:139-147.

9. Sethuramalingam TA, Haniffa MA. Effect of Formulated diet on digestive enzymes in Labeo rohita (Ham), I J Exp Biol. 2001;40(1):8388.

10. Keshavanath P, Gangadhara B, Khadri S. Growth enhancement of carp and prawn through dietary sodium chloride supplementation. Aquacult Asia. 2003;8(4):4-8.

11. Kumar S, Fernando LG, Chakrabarti R, et al. Characterization of digestive proteases of three carps Catla catla, Labeo rohita and Hypophthalmicthys molitrix and in vitro digestibility study. Aquacult Nutr. 2007;13(5):1-9.

12. Mohapatra S, Chakraborty T, PrustyAK, et al. Use of different microbial probiotic in the diet, of Labeo rohitafingerlings; effects on growth, nutrient digestibility, and retention, digestive enzymes activities and intestinal microflora. Aquacul Nutr. 2012;18(1):1-11

13. Lowry HO, Rosebrough NJ, Farr AL, et al. Protein measurements with the Folin phenol reagent. J Biol Chem. 1951;193(1):265-275.

14. Kuntiz M. Crystalline soybean trypsin inhibitor, II. General properties. $J$ Gen Physiol. 1947;30(4):291-310.

15. Erlanger BF, Kokowsky M, Cohen W. The preparation and properties of two new chromogenic substrates for trypsin. Arch Biochem Biophy. 1961;95:271-278.

16. Nelson N. A photometric adaptation of the Somogyi method for the determination of glucose. J Biol Chem. 1944;153:375-380.

17. Al-Hussaini AH. The feeding habits and the morphology of the alimentary tract of some telosts living in the neighbourhood of the marine biological station, Ghardaque, Rod Sea. Publ Mar Biol Station. Ghardaqa (Red Sea). 1947;5:4-61.

18. Palaniswamy K. Studies on the digestive enzymes of the cultivable grey mullet Liza parsia (Hamilton Buchanan. 1822). Thesis Submitted in partial fulfilment of the requirements for the degree of Doctor of philosophy of the Cochin University of Science and Technology. 1989.

19. Matthes H. A comparative study of the feeding mechanisms of some African Cyprinidae. Bijdragen tot de Dierkunde. 1963;33:3-55.

20. Hsu YL, Wu JL. The relationship between feeding habits and digestive proteases of some freshwater fishes, Bull Inst Zoo Academia Sinica. 1979; $18: 45-53$.

21. Datta SN, Kaur VI, Dhawan A, et al. Estimation of length-weight relationship and condition factor of spotted snakehead Channa punctata (Bloch) under different feeding regimes. Springer Plus. 2013;2:436.

22. Kuz'mina VV. Season and age changes of $\alpha$-amylase activity in bream. VoprIcthyol (In Russian). 1980;17:111-133.

23. Nikolsky GV. The Particular Ichthyology, Soviet Nauka, Moscow. (In Russian) 458. 1954.

24. Poddubny AG. Ecological Topography of Fish Populations in Reservoirs, Nauka, Leningrad. (In Russian). 311. 1971.

25. Kuz'mina VV. Influence of age on digestive enzyme activity in some freshwater teleosts. Aquaculture. 1996;148(1):25-37.

26. Chakrabarti R, Rathore RM, Mittal P, et al. Functional changes in digestive enzymes and characterization of proteases of silver carp ( $\left.{ }^{1}\right)$ and bighead carp ( $(+)$ hybrid, during early ontogeny. Aquaculture. 2006;253(1-4):694-702. 
27. Akintunde EA. Digestive enzymes in the gut of Sarotherodon galileaus Syn. Tilapia galilaleo (Fam. Cichlidae) of Lake Kainji, Nigeria. Nig J Sci. 1984;18:22-250.

28. Kitamando M, Taichino S. Studies on the digestive enzymes of rainbow trout-II. Proteases. Bull Jap Soc Sci Fish . 1960;26(7):685-694.

29. Sinha. Project Co-ordinator's report. In Proceedings of the Fourth Workshop on All-India Coordinated Research Project on composite fish culture and fish seed production. Bhubaneswar, ICAR. 1978.

30. Rathore RM, Kumar S, Chakrabarthi R. Digestive enzyme patterns and evaluation of protease classes in catla (Family: Cyprinidae) during early developmental stages. Comp Biochem Physiol. 2005;142(1):98-106.

31. Sabapathy U, Teo LH. A quantitative study of some digestive enzymes in the rabbitfish, Siganus canaliculatusand the sea bass (Lates calcarifer). J Fish Biol. 1993;42(4):595-602.

32. Corrêa FC, de Aguiar LH, Lundstedt LM, et al. Responses of digestive enzymes of tambaqui (Colossoma macropomum) to dietary corn starch changes and metabolic inferences. Comp Biochem Physiol A Mol Integr Physiol. 2007;147(4):857-862.

33. Chakrabarti I, Gani MA, Chaki KK, et al. Digestive enzymes in 11 freshwater teleost fish species in relation to food habit and niche segregation. Comp Biochem Physiol. 1995;112(1):167-177.

34. Kawai S, Ikeda S. Studies on digestive enzymes of fishes. Effect of dietary change on the activities of digestive enzymes in carp intestine. Bull Jpn Soc Sci Fish. 1972;38(3):265-270.

35. Alarco'n FJ, Martinez TF, Diaz M, et al. Characterization of digestive carbohydrase activity in the gilthead seabream (Sparus aurata). Hydrobiologia. 2001;445(1):199-204.

36. Das KM, Tripathi SD. Studies on the digestive enzymes of grass carp, Ctenopharyngodon idella (Val.). Aquaculture. 1991;92:21-32.

37. Parra AMD, Rosas A, Lazo JP, et al. Partial characterization of the digestive enzymes of Pacific bluefin tuna (Thunnus orientalis) under culture conditions. Fish Physiol Biochem. 2007;33(3):223-231.

38. Lundstedt LM, Melo JFB, Moraes G. Digestive enzymes and metabolic profile of Pseudoplatystoma corruscans (Teleostei: Siluriformes) in response to diet composition. Comp Biochem Physiol Part B. 2004;137(3):331-339.
39. Papoutsoglou ES, Lyndon AR. Distribution of $\alpha$ - amylase along the alimentary tract of two Mediterranean fish species, the parrotfish Sparisoma cretense L. and the stargazer, Uranoscopus scaber L. Mediterranean Marine Sci. 2003;4(2):115-124.

40. Fagbenro OA. Food composition and digestive enzymes in the gut of pond-cultured Clarias isheriensis (Sydenham 1980), (Siluriformes Clariidae). J Appl Ichthyol. 1990;6:91-98.

41. Deguara S, Jauncey K, Agius C. Enzyme activities and $\mathrm{pH}$ variations in the digestive tract of Gilthead Sea bream. 2003.62(5):1033-1043.

42. Liu ZY, Wang Z, Xu SY, et al. Two trypsin isoforms from the intestine of the grass carp (Ctenopharyngodon idellus). J Comp Physiol B. 2007;177(6):655-666.

43. Singh BN. Nutrition and Feed formulation for carps, Souvenir, Fourth Advisory Committee Meeting of NACA (FAO/UNDP Project). Bhubaneswar, Orissa, India. 1984;53-67.

44. Uys W, Hecht T. Assays on the digestive enzymes of sharp tooth catfish, Clarias gariepinus (Pisces: Clariidae) Aquaculture. 1987;63(14):301-313.

45. Saha AK, Ray AK. Performance of rohu, Labeo rohita (Hamilton) fingerlings maintained on alternative feeding of plant and animal protein based diet. Acta Ichthyologica et Piscatoria. 1998a ;28(1):3-12.

46. Das KM, Tripathi SD. Studies on the digestive enzymes of grass carp, Ctenopharyngodon idella (Val.). Aquaculture. 1991;92:21-32.

47. Shcherbina MA, Kazlaskene OP. The reaction of medium and rate of absorption of nutrient in the intestine of carp, J Ichthyology. 1971;11:81.

48. Clark J, Mc Naughton, Stark JR. Metabolism in marine flatfish - I Carbohydrate digestion in Dover sole (Solea solea L). Comp Biochem Physiol. 1984;77(4):821-827.

49. Kawai S, Ikeda S. Studies on digestive enzymes of fishes. IV. Development of digestive enzymes of carp and black sea bream after hatching. Bull Japn Soc Sci Fish. 1971;39:877-881.

50. Sarogini KK. The food and feeding habits of the grey mullet, Mugil parsia Hamilton and Mugil speigleri,Bleeker. Indian J Fish. 1954;1:6793. 